\title{
MENGEMBANGKAN NILAI MORAL DAN DISIPLIN AUD MELALUI METODE BERCERITA
}

\author{
Ema Fatmawati ${ }^{1}$, Ema Huzaima ${ }^{2}$, Heni Nafiqoh ${ }^{3}$ \\ ${ }^{1}$ Kober Kinanti, Bandung Barat \\ ${ }^{2}$ Kp babakan Ampera Rt 05 Rw $16^{3}$ Desa jayagiri Kecamatan Lembang KBB \\ 1fatmawatiema051@gmail.com 2Ffebriani45@gmail.com \\ 3 heni.nafiqoh@yahoo.co.id
}

\begin{abstract}
Abstrac
moral is habit that every individual does both good and bads morals. The abudance of poor children's behaviors in the present is very worrying, lack of manners and lack of discipline in the lives of chidren now, while they are the nation's future candidates As our teachers and parents have very important task in instilling moral education and discipline to children starting from early childhood, with creating a learning system that is fun and can be acceptable to children but can teach about moral messages and discline. thourgh storytelling there are many moral messages that can be conveyed to the child, including good character messages, imagination education, and can build emotional closeness between teachers and children, so that the development of moral attitude and good discipline can be formed from early childhood.
\end{abstract}

\section{key word : moral, discipline, childhood}

\begin{abstract}
Abstrak
Moral merupakan suatu kebiasaan yang dilakukan setiap individu bisa perilaku yang baik dan buruk. Banyaknya perilaku-perilaku anak yang kurang baik dalam sekarang ini sangat memprihatinkan, kurangnya sopan santun dan kurangnnya disiplin dalam kehidupan anak di jaman sekarang, sedangkan mereka adalah calon-calon penerus bangsa Sebagai guru dan orang tua kita mempunyai kewajiban dalam menanamkan pendidikan moral dan disiplin kepada anak dimulai dari anak usia dini, dengan membuat sistem pembelajaran yang menyenangkan dan dapat diterima oleh anak namun dapat mengajarkan tentang pesan-pesan moral dan disiplin. Melalui bercerita ada banyak sekali ilmu yang bisa disampaikan kepada anak, meliputi pesan-pesan karakter yang baik, seperti pendidikan imajinasi, yang bisa membangun kedekatan emosional antara guru dan anak, sehingga perkembangan sikap moral dan disiplin yang baik dapat dibentuk dari sejak anak usia dini.
\end{abstract}

Kata Kunci : Moral, Disiplin, Anak Usia Dini

\section{PENDAHULUAN}

Memasuki abad 21 bangsa Indonesia akan mengalami tantangan dan masalah yang sangat komplek diantaranya krisis multidimensional, maupun persaingan global. Menghadapi kondisi tersebut dibutuhkan sumberdaya manusia yang berkualitas, untuk mewujudkan SDM yang berkualitas salah satunya melalui upaya pendidikan yang berkualitas. Pembentukan SDM yang berkualitas melalui pendidikan yang berkualitas melalui harus dimulai dari sejak dini. Usia dini. Hampir $80 \%$ otak anak berkembang, $50 \%$ berkembang pada usia 0-5 tahun, 30\% berkembang di usia 5-8 tahun (Dryden \& Vos, 2003). 


\section{JURNAL CERIA}

ISSN : 2614-6347 (Print) 2614-4107 (Online)

Vol.1 1 No.2 1 Maret 2018

Banyaknya perilaku-perilaku anak dijaman

sekarang yang kurang mengedepankan nilai-nilai moral dan disiplin didalam perilaku mereka saat ini, menjadi PR yang sangat besar untuk para orang tua dan pendidik, karena dimasa kanakkanak menjadi masa yang paling tepat untuk peletakan dasar-dasar moral dan disiplin.

Metode mendongeng merupakan pendekatan pembelajaran, yang sangat disukai anak-anak.. Bercerita dalam kegiatan pembelajaran yang dilakukan orang lain bisa menggunakan alat praga atau tidak tentang materi yang disampaikan dalam bentuk cerita. Bisa suatu informasi, atau hanya dongeng yang akan didengarkan dengan rasa menyenangkan. Tujuan kegiatan bercerita adalah untuk menanamkan pesan-pesan moral kepada anak sejak dini sehingga perkembangan sikap moral pada anak dapat dibentuk menjadi karakter yang membanggakan dalam perjalanan hidup anak kelak jika sudah dewasa.

Seperti yang telah dipaparkan diatas maka penulis dapat merumuskan permasalahan yang akan diteliti, diantaranya, seberapa pentingkah pengembangan moral dan disiplin anak pada usia dini, bagaimanakah pengaruh metode bercerita terhadap pengembangan moral dan disiplin anak, serta faktor-faktor apa sajakah yang menjadi kendala dalam mengembangkan moral dan karakter anak.

\section{KAJIAN TEORI}

\section{A. Pengertian Moral dan Disiplin}

Moral merupakan suatu kebiasaan atau perilaku yang biasa di lakukan baik perilaku yang baik atau buruk. Moral berasal dari bahasa latin yaitu "Mores"yang bermakna suatu adat atau budaya. Moral juga mempunyai arti budaya yang biasa dilakukan di masyarakat.

Paiget mengemukakan moral merupakan kecenderungan menerima, menaati sistem peraturan. karakter yang baik tidak dibawa sejak lahir tetapi sesuatu yang harus dipelajari sehingga dapat menjadi suatu perilaku yang bisa diimplementasikan dalam kehidupan bersosial di masyarakat.. Jadi perkembangan moral mencakup aspek kognitif yaitu pengetahun tentang baik dan buruk, benar atau salah, dan faktor afektif yaitu sikap atau moral tersebut dipraktikan. (Mursid, 2015).

\section{B. Tahapan Perkembangan moral}

Menurut Kohlberg (Mursid, 2015) ada tiga tahapan perkembangan moral yaitu:

\section{TingkatanTahapan \\ Prokonvesional}

Aturan ini berisi tentang ukuran moral yang dibuat otoritas lembaga terkait. Pada tahapan perkembangan anak-anak sikap moral dapat dilihat dari perilaku anak dalam kehidupan bersosialisasi di lingkungan sekolah maupun dirumah. tingkatan perkembangan moral meliputi Tahap orientasi terhadap aturan yang berlaku pada tahap ini anak hanya mengetahui sebuah aturan yang harus di patuhi. yang kedua 


\section{JURNAL CERIA}

ISSN : 2614-6347 (Print) 2614-4107 (Online)

Vol.1 1 No.2 1 Maret 2018

Tahap Relativistik, pada tahapan ini anak sudah tidak lagi tergantung pada peraturan yang ada disekitarnya, tetapi anak sudah mempunyai kesadaran sendiri bahwa setiap kejadian mempunya dampak atau sebab akibat yang akan ditimbulkan

\section{Tingkatan Tahapan Konvensional}

Pada tahapan ini anak akan merasa terikat dengan peraturan yang telah ditetapkan bersama sehingga anak akan diterima oleh lingkungan sosialnya.

\section{Tingkatan Tahapan Pascakonvensional}

Pada tahapan ini anak mematuhi peraturan untuk menghindari hukuman kata hatinya, anak mulai merasa tidak enak jika melanggar peraturan yang berlaku.

\section{Disonansi Moral}

Pada hakikatnya posisi anak sebagai manusia memiliki tiga macam tenaga dalam yang ada dalam unsur psikis keberadaan tenaga dalam itu akan memberikan pengaruh pada dirinya untuk melakukan kekuatan dan aktivitas positif maupun negative dorongan ketiga tenaga dalam ini yang perlu dicermati, menurut istilah psikologi dikenal dengan : id, ego, dan super ego.

a. Id, merupakan motivasi yang dari dalam diri seseorang untuk mendahulukan rasa enak, untuk mencapai kenikmatan dan nafsu belaka.

b. Ego, adalah ibarat suatu dorongan atau tenaga dalam yang berasal dari jiwa seseorang yang berpungsi menyeimbangkan kemauan dari id dengan mencoba mengarahkan dorongan tersebut dalam kenyataan hidup. c. Super Ego, adalah dorongan atau tenaga dalam yang berpungsi sebagai alat control terhadap suatu dorongan yang berasal dari kemauan, id control dari super ego disini adalah dari ajaran agama, moral, atau norma yang diajarkan dan diterima manusia.

Suatu contoh ilustrasi dalam memahai istilah Id, Ego dan super ego yaitu: ketika anak disuruh mandi sore oleh ibunya tetapi ia tetap ingin bermain dan tidak perlu mandi (ini dinamakan Id) kemudian ibunya menasehati dengan mengutip ucapan buguru yang harus menjaga kesehatan kita harus mandi (Super Ego) kemudian anak tersebut melihat teman sebayanya sudah mandi tinggal dia sendiri yang belum (Ego) disitulah peran orang tua / guru dalam mengarahkan sesuatu yang timbul dari anak kearah yang positif dengan pendekatan pendidikan. Dalam teori penanaman moral dan etika ini biasa dikenal sebagai istilah" Disonasi Moral" (Mursid, 2015).

\section{Metode Bercerita}

Metode berasal dari bahasa Yunani methodos mempunyai arti adalah cara yang ditempuh untuk mencapai sebuah tujuan yang sudah ditentukan atau direncanakan sehubungan dengan upaya ilmiah. Fungsi metode berarti sebagai alat untuk mencapai tujuan, atau bagaimana cara melakukan sesuatu atau membuat sesuatu.

Metode bercerita adalah penyampaian atau penyajian materi pembelajaran secara lisan 


\section{JURNAL CERIA}

ISSN : 2614-6347 (Print) 2614-4107 (Online)

Vol.1 1 No.2 1 Maret 2018

dalam bentuk cerita dari guru terhadap anak didiknya. Tujuan bercerita adalah agar anak mampu mendengarkan secara seksama terhadap apa yang disampaikan orang lain dengan cara yang menyenangkan dan menghibur, sesuai dengan peraturan pemerintah No. 19 tahun 2005 tentang Standar Nasional Pendidikan, pasal 19 ayat 1, yang menyatakan bahwa proses pembelajaran pada satuan pendidikan diselenggarakan secara interaktif, inspiratif, menyenangkan, menantang, memotivasi peserta didik. (Asmawati, 2014).

\section{Pembahasan}

Pendidikan Anak Usia Dini pada dasarnya merupakan pemberian stimulasi, membimbing, mengasuh, dan memberikan pengalaman kegiatan pembelajaran yang akan mengembangkan kemampuan anak. Pendidikan pada anak usia dini merupakan sebuah pendidikan yang dilakukan pada anak baru lahir sampay usia delapan tahun. Pendidikan pada tahap ini memfokuskan pada: physical, intelegence, emotional, social education. (Mursid, 2015).

Berdasarkan peraturan pemerintah tentang standar pendidikan anak usia dini meliputi bimbingan dan pengasuhan serta pemberian pengalaman pembelajaran agar anak dapat berekplorasi dengan lingkungannya. melalui cara mengamati, meniru dan berekperimen yang berlangsung secara berulang-ulang dan melibatkan seluruh potensi dan kecerdasan anak.

Dalam penyajian bercerita untuk anak sangat penting sekali memperhatikan jenis-jenis dan teknik dalam menyampaikan metode bercerita, olah vocal dan olah gerak dan bahasa serta ekpresi sangat mempunyai peranan penting dalam kegiatan bercerita, ekpresi wajah atau mimik, ilustrasi suara, dan alat pendukung yaitu alat peraga sangat mendukung dalam keberhasilan dalam kegiatan bercerita.

1. Pengaruh Metode Bercerita Terhadap Disiplin dan pengembangan Moral Pada anak pra sekolah.

Kegiatan Bercerita memainkan peranan yang sangat penting bukan hanya menumbuhkan kebiasaan membaca, tetapi dapat mengembangkan perkembangan bahasa pada anak. Bercerita merupakan metode komunikasi yang sangat berpengaruh pada pembentukan mental dan perilaku anak.. Cerita yang didengarkan sejak usia dini akan menjadi suatu kenangan yang sangat berarti di kemudian hari. Nilai-nilai kehidupan yang terserap akan dapat diaplikasikan kedalam kehidupannya, dengan begitu cerita memiliki pengaruh yang sangat kuat dalam pembentukan karakter anak.

Manfaat bercerita dalam proses pembelajaran dapat membangun kedekatan emosional dan sebagai salah satu media penyampai pesan. Cerita biasanya memiliki nilainilai kehidupan tertentu dan mengandung pesan moral dan disiplin dalam kehidupan sehari-hari. Pada hakikatnya anak lebih senang mendengarkan kisah daripada diberitahu langsung apalagi diperintah, dengan mengajarkan nilai-nilai moral dan disiplin melalui 


\section{JURNAL CERIA}

ISSN : 2614-6347 (Print) 2614-4107 (Online)

Vol.1 | No.2 I Maret 2018

kegiatan bercerita akan lebih lebih efektif.

Dengan menyelipkan pesan moral dan disiplin pada setiap cerita yang dibacakan dengan sendirinya akan masuk kedalam pikiran dan imajinasi anak, karena pada hakikatnya anak usia dini merupakan seorang peniru yang sangat hebat, anak akan melakukan apa yang ia lihat dan apa yang dia dengar.

\section{a. Pendidikan Imajinasi / Fantasi}

Berkhayal dan berimajinasi yaitu merupakan terapi jiwa yang utama untuk usia 0-6 tahun. kreatifitas, imajinasi dan fantasi juga mendorong anak untuk mempunyai keingin tahuan yang tinggi.

b. Memperkaya Pengalaman Batin Dan alat penghibur yang menarik perhatiannya

Melalui didengarkan dongeng untuk usia 0-6 tahun akan melatih pemahaman mengenai makna kehidupan, seringnya anak mendengarkan cerita jadi kenyataannya yang dialaminya akan banyak juga sangat bagus untuk kematangan jiwanya. peserta didik akan mengalami perkembangan yang kuat serta bertanggung jawab mengenai hal yang dialami dalam hidupnya. Kegiatan bercerita di tengah kejenuhan dan kebosanan anak dalam belajar, jika diselipkan kegiatan bercerita maka anak akan merasa fres dan segar kembali juga mendapatkan keadaan yang energik pada saat pembelajaran.

c. Kendala-kendala yang dihadapi dalam pengembangan moral dan disiplin pada

\section{Anak usia Dini}

Peran keluarga sangat berpengaruh kepada perkembangan nilai moral dan bertanggung jawab pada usia 0-6 tahun merupakan pengetahuan yang utama yang harus dilakukan oleh orang tua. Pendidikan moral dan disiplin dimulai dari lingkungan yang terdekat anak yaitu keluarga, kebiasaan-kebiasaan yang biasa dilakukan dirumah akan sangat berpengaruh kepada perlakuan peserta didik di sekolah dan didalam pergaulannya. Dengan membiasakan bercerita di lingkungan keluarga dengan membudayakan lagi bercerita sebelum tidur sangat penting untuk perkembangan anak, dan penanaman moral disiplin terhadap anak usia dini.

\section{2) Pengaruh Eksternal}

Peran sekolah dalam menerapkan aturan disiplin yang jelas serta perencanaan program kegiatan pembelajaran yang memasukan muatan karakter dalam setiap kegiatan pembelajaran melalui metode bercerita sangat berperan penting dalam perkembangan pengetahuan anak usia dini. Dengan program kegiatan pembelajaran menggunakan metode bercerita pada anak diharapkan anak akan terstimulasi dengan isi cerita yang disampaikan melalui karakterkarakter/ tokoh-tokoh dalam cerita dengan sendirinya anak akan meniru peserta didik mampu menirukan yang dilakukan orang dewasa dengan baik. 


\section{JURNAL CERIA}

ISSN : 2614-6347 (Print) 2614-4107 (Online)

Vol.1 $\mid$ No. 2 |Maret 2018

\section{Simpulan}

Bercerita yaitu alat yang menarik dan meriah bagi anak, setiap anak pasti sangat menyukai kegiatan bercerita di tengah kejenuhan dan kebosanan anak dalam belajar, jika diselipkan kegiatan bercerita maka anak akan merasa fres dan segar kembali. Cerita juga daapat bermanfaat dalam hiburan juga menumbuhkan semangat dalam pembelajaran.

Dengan menyimak dongeng maka akan menumbuhkan pemahaman beberapa makna kehidupan, seringnya anak mendengarkan kisahkisah yang mengagumkan maka pengalaman batinnya akan lebih kaya dan sangat bagus untuk kematangan jiwanya, akan menumbuhkan sikap yang tidak mudah putus asa juga berprinsif di kehidupannya.

Kegiatan bercerita baik mengenai pengelamannya maupun pengalaman kawankawannya dengan penghayatan akan menumbuhkan perasaanya kepada anak sesuai dengan sifat-sifat pelaku dalam dongeng tersebut, jalinan batin berupa ekpresi yang diolah oleh guru akan membangun kedekatan emosional anak, rasa sayang, hormat, empati dan keteladanan natural dalam kegiatan pembelajaran.

\section{E. Saran}

Peran keluarga sangat berpengaruh kepada perkembangan nilai moral dan kepatuhan pada usia 0-6 tahun merupakan pembelajaran yang pertama dalam lingkungan rumahnya. Pendidikan moral dan disiplin dimulai dari lingkungan yang terdekat anak yaitu keluarga, kebiasaan-kebiasaan dilakukan dirumah akan sangat berpengaruh pada tingkah laku peserta didik di sekolah dan didalam pergaulannya. dengan membiasakan kegiatan bercerita yang berawal dari keadaan rumahnya dengan membudayakan lagi mendongen sebelum tidur sangat penting untuk perkembangan anak.

Dengan program kegiatan di sekolah yang menetapkan mi oleh anak, serta kegiatan pembelajaran bercerita yang memasukan nilainilai moral dan disiplin, diharapkan perkembangan kepribadian anak akan tumbuh sesuai harapan.

Adanya kerja sama antar pihak sekolah dan pihak keluarga demngan melalukan pembinaan secara rutin kepada keluarga mengembangkan sikap moral juga kepatuhan pesefta didik diharapkan ada suatu harmoni kesesuaian dengan pengetahuannya yang dilaksanakan dalam keluarga dan pendidikan yang dilaksanakan di sekolah..

\section{DAFTAR PUSTAKA}

Asmawati, L. (2014). Perencanaan pembelajaran PAUD. Bandung: PT REMAJA ROSADAKARYA.

Mursid. (2015). Belajar dan pembelajaran PAUD Bandung. Bandung: PT REMAJA ROSADAKARYA. 